\title{
Hotel Revenue Management Implementation in Hotel
}

\author{
Arif Zulkarnain, Anita Swantari, Haryo Wicaksono \\ Diploma IV Hotel \\ Sekolah Tinggi Pariwisata Trisakti \\ Jakarta, Indonesia \\ Email: arifzulkarnain@stptrisakti.ac.id,
}

\begin{abstract}
Hotel Revenue Management is the application of information systems and pricing strategies that sell the right place to the right customers at the right time and in the right time frame. Implementation of hotel revenue management is done through the seven steps that aim to identify and resolve problems arising from Revenue Management. Which stipulates Market segmentation, Availability, Product Differentation, Demand Forecast, Price Management, Overbooking Classes, Reservation Negotiation. This study uses a cross section analysis. Where this approach is a method that describes the state at a given time, ie the state of Average Room Rate,\% Occupancy, RevPAR, and TREVPEC. Data mining from the primary data using, among others: conducting interviews to the General Manager, Front Office Manager, and Chief Accounting. The result found several indicators, namely: in February has Room Occupancy, Average Room Rate, TrevPec the lowest compared to other months in the year 2015. the highest value of each indicator, namely: Room Occupancy in November, the Average Room Rate and RevPAR in August, and TrevPec in September. Managerial implications: the application of revenue management will provide better preparation for operational hotel. particularly in facing low occupancy in February to prepare planning in terms of promotion and targeting new segmentation.
\end{abstract} words)

Keywords-component; formatting; style; styling; insert (key

\section{INTRODUCTION}

In this era of globalization, travel is a necessity that cannot be avoided by humans. This has an impact on business development in Indonesia. One among a growing business that is in the field of hospitality, not least in Jakarta as the Metropolitan City. Today the hotel business is growing very rampant in Jakarta, this can be seen from the number of new hotels popping up.

With their many competitors are emerging, each hotel has to create its own uniqueness that can be always remembered by the guests. Last but not least the hotel should be able to manage resources owned efficiently and effectively so as to remain competitive. By executing the process of managing the resources had, the hotel business will get the results in the form of revenue for the development process.

Revenue is the main goal to be achieved by the owner or general manager if it is to develop the hotel business. According to Miller, Hayes, and Dopson (2002), the owner or manager can set the level of income, income itself is a result of the sale of units have been sold. With an aim to increase revenues and to remain competitive with rivals in running a hotel business through management processes.

Revenue management is the right thing to implement. Revenue management is the application of information systems and pricing strategies that sell the right place to the right customers at the right time and in the appropriate period (Kimes, Chase, Choi, Lee \& Ngonzi, 1998).

Application of revenue management hotel itself will support any hotel that wants to remain competitive in the hospitality industry. Keep in mind, In this research, the Hotel is a four star hotel. Based on interviews conducted earlier, General Manager explained that the hotel already has clear standards of service procedures so that it can be said that the services carried out using the standard operating procedure.

Based on the background above, this research aimed to analyze hotel revenue management in hotels "XY" and how the hotel could implement it. To understand more about the hotel revenue management, 7-step approach to implement revenue management, which stipulates Market segmentation, Availability, Product differentation,, Demand Forecast, Price Management, Overbooking Classes, Reservation Negotiation (Sevinc Gökşen, 2011).

According to Sevinc Gökşen (2011), revenue management is a technique that helps large corporations or small and medium enterprises to achieve the highest profit to correctly identify groups of customers that the company should be serving, building right (quantity) of products and services and prepare the optimal price to be offered to these customers. 7 step approach to implement revenue management, which stipulates Market segmentation, Availability, Product differentation,, Demand Forecast, Price Management, Overbooking Classes, Reservatin Negotiation. According Kimes (1994), Revenue Management is a method that helps companies to sell inventory at the right consumer at the right time and the right price. Revenue management guide decisions on how to allocate the limited capacity of the unit to the existing demand in order to maximize revenue.

"Revenue is the inflow or increase in the value of assets of an entity or redemption of debt (or a combination of both) for a specific period which is derived from the delivery or manufacture of goods. The provision of services, or the implementation of other activities which are the main activities of the entity's ongoing ".(Belkaoui 2000).

According to Ivanov (2014), the definition of yield management / revenue can be described as follows: 
a. The optimal level of net income of the hotel and the gross operating profit Net income of the hotel include sales income after taxes and commissions. The gross operating profit is equal to net income less costs to serve customers (cost of goods sold, marketing, administration, and human resource costs) (Dopson and Hayes (2009)). Maximizing net income does not mean that the gross operating profit will be at the maximum level of potential. For example, attract additional customers to the hotel will cost too expensive to serve, so that gross profit will actually decline.

b. Right Consumers

Not all customers are equally profitable for hotels. Some of them are too costly expensive to be served, as they may have too high requirements that the hotel could not be simpler to implement, while others are willing to pay the price too low that could barely cover the cost of the hotel. Consumers right is a marketing concept, but can be associated with the target market segments that have been identified by the marketing manager of the hotel and the requirements considered when preparing the product from the hotel.

c. The right product

Rights the right product is determined by consumers and hoteliers. The right products are:

1) Products that provide value to the customer the right to satisfy the needs, desires, and their requirements.

2) Products that reflect the willingness of customers to pay.

3) Products are profitable for the hotelier.

d. The appropriate distribution channel

Hotels can sell its products through various distribution channels, such as selling directly to customers, through travel agents, online travel agent (OTA / Online Travel Agent), global distribution system (GDS / Global Distribution Systems), an online reservation system, etc. (Ivanov \& Zhechev 2011).

e. The right price

Price is one of the most important instruments in the management of yield / revenue because it is directly related to income level. By changing the price level over time, the ratio between the price will be different for different segments of the market (the so-called "price structure") and conditions applicable to each level of hotel prices to attract consumers the most accurate and high revenue.

f. The right time

Time is one of the most important concepts in the management of revenue. Offer the same can be perceived differently simply on the basis of time. For example, a promotion to stay when pre-Christmas offered in July are likely to be more attention because it was published too early. The same offer at the beginning of December may be inefficient.

g. Proper Communication

In the management of yield / revenue, marketing communications of the hotel influence how products and prices are felt. The information provided on the website or how prices are presented can affect customer perception of value that they can receive from consuming products from the hotel and the reasonableness of pricing conditions.

Here is a description of a 7-step approach to implementing revenue management, which stipulates Market segmentation, Availability, Product Differentiation, Demand Forecast, Pricing Management, Booking classes and Reservation Negotiation (Sevinç Gökşen, 2011).

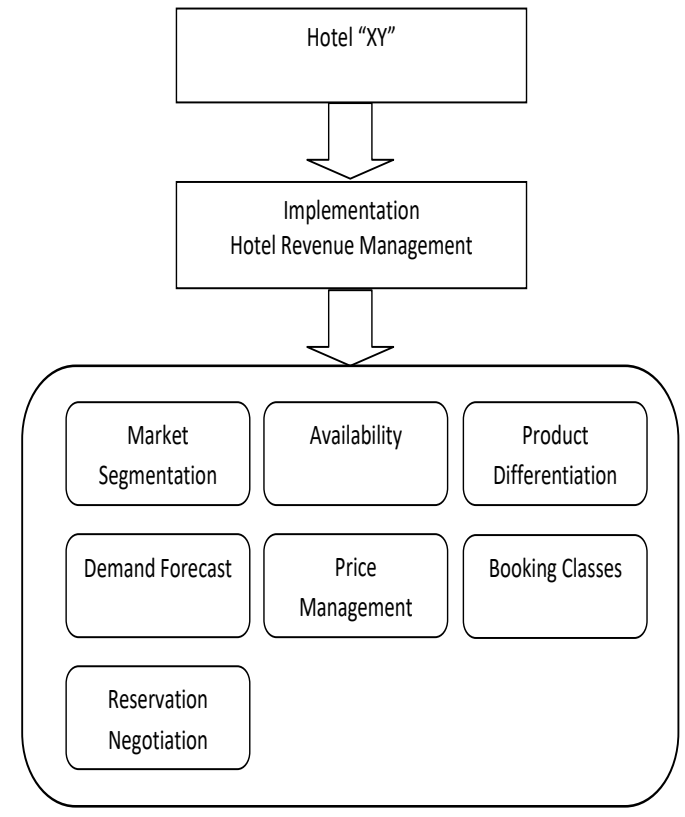

Fig. 1. Implementing of Revenue Management. (Sevinç Gökşen, 2011)

The research is aimed to understand if Hotel "XY" implement revenue management hotel in running business operations.

\section{METHOD}

Type of research is a case study which is one type of qualitative research, where researchers conducted in-depth exploration of the program, event, process, activity, to one or more people. A case is bound by time and activity, and researchers conducted detailed data collection by using various data collection procedures and in continuous time. (Creswell, 2009). The type of data in this study is qualitative data which is data about the general picture of the hotel and the data to support the various activities associated with the implementation of hotel revenue management. The data used in this research is the source of primary data and secondary data sources. Primary data is data obtained directly from the authorities in the management, their observations and the results of interviews with informants in "XY". Secondary data is data obtained indirectly, data sourced from the hotel as well as of literature related to the implementation of hotel revenue management.

Methods of data collection in this study by using observation and interviews to the General Manager, Front 
Office Manager and Chief Acounting to identify the implementation of hotel revenue management at the hotel.

The operational variables are establishing the factors of the performance of Hotel "XY" which includes:

a. Calculate\% Occoupancy

b. \% Occoupancy is the number of rooms sold divided by the number of rooms available

c. Calculate RevPAR

d. RevPAR is room sales revenue divided by the number of rooms available

e. Calculating the Average Room Rate

f. Average Room Rate is the average price per room by comparing the income earned from the rooms to the number of rooms sold.

g. TREVPEC is total revenue divided by the number of clients.

Data analysis technique in this research by using qualitative descriptive technique which describe the implementation of revenue management of the hotel proficiency level. Data analysis technique is carried out as follows:

a. Descriptive Analysis

This descriptive analysis describes all the results of research based on observation, interviews and documentation of hotel room sales data.

b. Analysis Evaluative

Evaluative analysis in this study is the result of a study on the policy hotel operations associated with the implementation of hotel revenue management conducted at the hotel "XY". The criteria used to ensure that hotel hotel revenue management has implemented or not based on the application of a five-step approach to hotel revenue management at the hotel. If the hotel has not been applying component overall hotel revenue management, means the hotel have yet to implement revenue management hotel.

c. Analysis Conclusive

Conclusive analysis in this study is the result of the conclusion of the hotel revenue management implementations in the hotel in the daily operational activities.

\section{RESULT}

Hotel "XY" has implemented revenue management hotel. In addition to research on the author to implement measures approach to the Hotel Revenue Management proposed by Sevinc Gökşen (2011), and found several indicators, namely: in February has Room Occupancy, Average Room Rate, TrevPec the lowest compared to other months in the year 2015. the highest value of each indicator, namely: Room Occupancy in November, the Average Room Rate and RevPAR in August, and TrevPec in September.
TABLE I. RESULT OF THE RESEARCH

\begin{tabular}{lll}
\hline Y'2015 & \% Occ. & ARR \\
\hline Hi & Nov 88,30\% & Aug \\
& & Rp.682.671,- \\
Lo & Feb, & Nov \\
& 69,8 & Rp.662.999,- \\
\hline & & \\
\hline Y'2015 & RevPAR & TREVPEC \\
\hline Hi & Aug, Rp.585.690,- & Sep, \\
& & Rp.650.313, \\
Lo & & - \\
& Feb Rp.474.114,- & Feb, \\
& & Rp.429.360, \\
\hline
\end{tabular}

\section{CONCLUSION}

The conclusion are as follows:

a. With the existing findings that the lowest point Room Occupancy, RevPAR and TREVPEC in February 2016, it is advisable to analyze market segmentation is not optimal on revenue earned.

b. The program design package that is providing more value so that more guests visiting Hotel.

c. Studying the historical aspec loyal guests who have to keep a degree of loyalty and give surprise and special gift to them.

d. Make a special event in order to attract more customers (Valentine package, Romantic Dinner).

e. Conducting training in up-selling with quantity more than it already is and the quality of the materials are weighted. As more and more employees of the hotel doing training, the better the service that will be provided to visitors for more hotels in spending money.

Managerial implications for hotel is that the application of revenue management will provide better preparation for operational hotel. particularly in facing low occupancy in February to prepare planning in terms of promotion and targeting new segmentation.

\section{REFERENCES}

Creswell, John W. (2009). Research Design: Qualitative, Quantitative, and Mixed Methods Approaches 3rd Edition, USA, SAGE Publisher.

Danim, S. (2002). Being a qualitative researcher. Faithful Reader. Bandung. Free discussion. (N.d.) Retrieved March 24, 2013, from http://id.shvoong.com/writing-andspeaking / presenting / 2061554-sense-income /

Hayes, D.K. and Dopson, L.R. (2011). Food and beverage cost control: Fifth edition. New York: John Wiley \& Sons, Inc.

Indonesia Institute of Accountants, (2010). Statement of Financial Accounting Standards / IAS 23. Retrieved March 26, 2013 from www.iaiglobal.or.id

Ivanov, Stanislav H, (2014). Hotel Revenue Management: From Theory to Practice, Edition: 1, Publisher: Zangador, Varna University of Management. 
Kimes, S.E. (1994), Perceived fairness of yield management, the Cornell Hotel and Restaurant Admnistration Quarterly, 29 (1), 22-29.

Kimes, S.E., Chase, R.B. (1998), The strategic evers of yield management, Journal of Service Research, 1(2), pp. 156-66.

Kimes, S.E., Chase, R.B., Choi, S., Lee, P.Y. \& Ngonzi, E.N. (1998). Hotel revenue management: Applying yield management to the hotel industry. Cornell Hotel and Restaurant Administration Quarterly, June 1998; 39.3. Retrieved March 23, 2013, from ABI / INFORM Global (Proquest) database.

Kimes, S.E. (1999), Implementing restaurant revenue management: A five-step approach.

Cornell Hotel and Restaurant Administration Retrieved March 25, 2013 from http://yieldmix.com/restaurant_revenue.pdf

Kimes, S.E., Wirtz, J. \& Noone, B.M. (2002). How long should take dinner? Journal of Revenue and Pricing Management, 4 (1), 220-233.

Kimes, S.E. (2004), Restaurant revenue management: Implementation at Chevys arrowhead, Cornell Hotel and Restaurant Admnistration Quarterly, 45 (1), 52-67.
Kotler, P. (1991). Marketing management: analysis, planning, implementation and control. Prentice Hall Inc., New Jersey.

Miller, J.E., Hayes, D.K. and Dopson, L.R. (2002). Food and beverage costs. New York: John Wiley \& Sons, Inc.

Ninemenier, D. \& J. Hayes, D. K. (2006). Restaurant operations management principles and practices (1st ed.). New Jersey: Pearson Prentice Hall.

Sevinc Gökşen (2011), Implementing of Revenue Management Vrije Universiteit Amsterdam Faculty of Sciences Business Mathematics and Informatics De Boelelaan.

Schmidgall, R.S., Hayes, D.K. and Ninemeier. J.D. (2002). Restaurant financial basics. New Jersey: John Wiley \& Sons, Inc.

Walker, J. R. (2004). Introduction to hospitality management. New Jersey: Pearson Education Inc.

Wyckoff D. D. (2001). New tools for Achieving service quality. Cornell Hotel and Restaurant Administration Quarterly, 44(1), pp. 53-60. 